\title{
PENGARUH PENAMBAHAN EKSTRAK BUAH DURIAN (Durio zibethinus Murr.) TERHADAP DAYA TERIMA YOGURT TEMPE
}

\author{
Oleh: \\ Herlin Yuliani, _Dwi Soelistya Diah Jekti, dan Dewa Ayu Citra Rasmi \\ Program Studi Pendidikan Biologi PMIPA FKIP Universitas Mataram
}

Tempe dapat dibuat menjadi yogurt, namun rasanya kurang disenangi. Padahal dilihat dari kandungannya, yogurt tempe memiliki banyak manfaat. Salah satu cara dalam mengatasi hal tersebut adalah dengan menambah perasa dari sari buah durian. Durian memiliki citarasa yang kuat dan banyak digemari masyarakat. Berdasarkan permasalahan tersebut penelitian ini bertujuan untuk mengetahui pengaruh penambahan ekstrak buah durian terhadap penerimaan yogurt tempe. Penelitian ini meliputi: membuat yogurt tempe dan ditambah ekstrak buah durian kemudian dilakukan uji daya terima masyarakat pada yogurt tempe tersebut. Rancangan penelitian yang digunakan adalah rancangan acak lengkap dengan percobaan satu faktor tunggal, yaitu perbandingan konsentrasi ekstrak buah durian, terdiri dari $0 \%, 10 \%, 20 \%$, dan 30\%. Pengambilan data dilakukan dengan uji hedonik (scaling test) terhadap 50 panelis konsumen di Taman Udayana Mataram. Data dianalisis menggunakan Analisis sidik ragam dan dilanjutkan dengan uji BNT pada taraf signifikansi $95 \%$. Kesimpulan yang diperoleh dari penelitian ini adalah penambahan ekstrak buah durian berpengaruh terhadap penerimaan yogurt tempe baik untuk indikator organoleptik warna, aroma, dan rasa. Penerimaan yang paling baik diperoleh pada perlakuan penambahan ekstrak buah durian $30 \%$.

Kata kunci : ekstrak buah durian, daya terima, yogurt tempe

\section{ABSRTACT}

Tempeh can be converted into yogurt. Although, based on its content, yogurt is very useful, it does not taste nice. One of the ways to make its taste nice is to add durian favor. Durian contains so good favor, so that people like it. Based on the problem, the present study aims at ascertaining the effect of the addition of durian extract on the acceptance rate of yogurt tempeh. The research procedures involve: making tempeh yogurt, adding durian extract to tempeh, and testing the people acceptance of the yogurt tempeh. The present study employs complete random design using single factor experiment, that is, the concentration percentages of durian essence are 0\%, 10\%, 20\% and 30\%. Data were collected with Hedonic Test (scaling test) to 50 consumer panelists at Udayana Mataram Park. Data were analysed using ANOVA continued with BNT test at level of significance 95\%. It shows that the addition of durian extract (or essence) affects the acceptance rate of tempeh yogurt as indicated by organoleptic indicators color, aroma and taste. The highest acceptance rate is found at the treatment with durian extract $30 \%$.

Keywords: durian fruit extract, acceptance rate, tempeh yogurt 


\section{PENDAHULUAN}

$\mathrm{T}$ empe sudah dikenal sebagai bahan makanan yang kaya gizi. Namun tempe termasuk bahan makanan yang mudah rusak, daya tahannya tidak lama, kurang lebih 72 jam pada suhu kamar. Pengolahan tempe secara konvensional seperti digoreng atau direbus dapat merusak zat gizi yang terkandung pada tempe oleh pemanasan selama proses memasak. Untuk mendapatkan nilai tambah dalam peningkatan nilai gizi dan penerimaan konsumen terhadap produk tempe perlu dilakukan upaya dalam pengolahan tempe. Tempe telah dicoba dikembangkan untuk penyedap rasa alternatif sebagai pengganti MSG (monosodium glutamat). Machin (2012) telah berhasil menghidrolisis tempe menghasilkan asam glutamat. Pada uji organoleptiknya diketahui bahwa food additive sebagai penyedap rasa alternatif berbahan hidrolisat tempe tersebut menghasilkan cita rasa sama dibanding penyedap rasa komersial. Kusumaningrum (2004), menyatakan bahwa tempe dapat dibuat minuman kesehatan yaitu yogurt.

Pengolahan tempe melalui fermentasi diharapkan dapat memberikan nilai tambah pada produk tempe berupa nilai gizi serta sebagai salah satu minuman prebiotik. Pengolahan tempe menjadi yogurt dapat meningkatkan antioksidan, bahkan dapat menimbulkan antioksidan baru, yaitu hydroxiantralinic acid (3-haa) yang lebih kuat dari vitamin $\mathrm{E}$ dan isoflavon sehingga bisa langsung menangkal radikal bebas dan memperbaiki kerusakan hati. Namun kehadiran yogurt tempe ini masih kurang diminati dikarenakan rasa yang dimiliki lebih asam dibanding dengan yogurt susu (Fuzhu, 2010). Untuk itulah perlu dilakukan kajian tentang penambahan citarasa pada yogurt tempe agar yogurt tempe lebih disukai oleh masyarakat mengingat manfaat yang sangat tinggi dari yogurt tempe ini. Ekstrak buah durian sering digunakan sebagai penambah citarasa pada makanan, karena durian adalah buah yang cukup digemari oleh masyarakat dan memiliki aroma yang cukup tajam sehingga diharapkan dapat mempengaruhi aroma dan citarasa yogurt tempe agar.

\section{METODE PENELITIAN}

Penelitian ini bersifat eksperimen yaitu dengan menambahkan ekstrak buah durian pada yogurt tempe. Metode kerja meliputi beberapa tahap yaitu: pembuatan susu tempe, pembuatan ekstrak (sari) buah durian, pembuatan yogurt tempe dengan penambahan ekstrak buah durian, dan uji penerimaan produk yogurt tempe yang dihasilkan.

1. Pembuatan ekstrak tempe (dimodifikasi dari Amaliah, 2002)

Tempe dipilih yang berkualitas baik merk H.Sallam yang dicirikan dengan miselium yang rata berwarna putih kompak dan beraroma khas tempe yang diperoleh dari produsen tempe kedelai Abian Tubuh Cakranegara sebanyak $1 \mathrm{~kg}$ dipotong kecil-kecil, kemudian dihaluskan dan ditambah 6 liter air panas, kemudian disaring sehingga diperoleh sari tempe. Sari tempe kemudiam dipasteurisasi pada suhu $80^{\circ} \mathrm{C}$ selama 15 menit, lalu didinginkan.

2. Pembuatan estrak durian

Buah durian kani yang diperoleh dari penjual durian daerah Sesaot dipilih yang sudah masak yang dicirikan dengan aroma durian yang khas. Buah durian dikupas, kemudian salut biji dipisahkan dari biji. Salut biji ditambahkan air dengan perbandingan $1: 1 / 2 \quad(\mathrm{~g} / \mathrm{mL})$, kemudian disaring. Sari buah durian hasil penyaringan dipasteurisasi pada suhu $80^{\circ}$ C selama 15 menit dengan ditambahkan $5 \%$ sukrosa kemudian didinginkan.

3. Pembuatan yogurt tempe + penambahan ekstrak buah durian

Ekstrak tempe ditambahkan susu skim $5 \%(\mathrm{~mL} / \mathrm{mL})$ dan gelatin $0,5 \%$ $(\mathrm{g} / \mathrm{mL})$, diinokulasi dengan starter yogurt 
sebesar 5\% (mL/mL). Ekstrak tempe yang telah diinokulasi kemudian diinkubasi pada suhu $42^{\circ} \mathrm{C}$ selama 8 jam (Kusumaningrum, 2004). Ekstrak buah durian dan sukrosa ditambahkan ke dalam yogurt setelah yogurt tempe selesai difermentasi (Widodo, 2002). Jumlah sukrosa yang ditambahkan sebanyak $5 \%(\mathrm{~g} / \mathrm{mL})$ dari jumlah yogurt tempe (Amaliah, 2002). Perbandingan konsentrasi ekstrak buah durian $(\mathrm{mL} / \mathrm{mL})$ yang terdiri dari: $\mathrm{Y} 0$ : yogurt tempe 100 $\%$ + ekstrak buah durian $0 \%, \mathrm{Y} 1$ : yogurt tempe $90 \%$ + ekstrak buah durian $10 \%$, Y2 : yogurt tempe $80 \%$ + ekstrak buah durian 20, Y2 : yogurt tempe $80 \%+$ ekstrak buah durian $20 \%$, Y3 : yogurt tempe $70 \%$ + ekstrak buah durian $30 \%$.

\section{Uji Penerimaan}

Penelis konsumen bertindak sebagai konsumen atau pengguna akhir dari produk yogurt yang dihasilkan sehingga dapat mewakili konsumen berdasarkan uji penerimaan yang dilakukan (SNI, 2006). Orang yang bertindak sebagai panelis dilihat keadaan fisik dan psikologisnya, diantaranya tidak sedang makan, tidak dalam keadaan terburu-buru, dan bersedia meluangkan waktu untuk menjadi panelis (Tridiyani, 2011). Waktu dan tempat pengujina Uji hedonik dilakukan pada hari Minggu tanggal 13 Januari 2013 pukul 09.00 - 11.00 WITA (Tridiyani, 2011). Uji hedonik dilaksanakan di Taman Udayana Mataram. Penentuan tempat tersebut ditentukan dengan mempertimbangkan jumlah panelis yang dapat diperoleh di lokasi tersebut tidak terbatas sehingga memungkinkan untuk diperoleh jumlah panelis sebanyak 50 orang panelis sesuai dengan jumlah yang diharapkan yang dapat memenuhi syarat dalam uji penerimaan (Arbi, 2012).

Teknik pengujian dilakukan dengan memberikan formulir penilaian untuk diisi oleh panelis. Formulir penilaian diisi dengan angka (skala 1-4) berdasarkan tingkat kesukaan panelis. Panelis menilai setiap sampel yang diujikan secara bergantian, untuk menetralkan indera pengecap panelis, digunakan air putih (Arbi, 2012).

Uji penerimaan untuk mengetahui kesukaan panelis terhadap sifat organoleptik (warna, aroma, dan rasa) yogurt tempe dengan penambahan ekstrak buah durian. Menetapkan produk yang paling disukai panelis berdasarkan tingkat kesukaan panelis terhadap yogurt tempe dengan penambahan ekstrak buah durian.

Teknik pengumpulan data

Data dalam penelitian ini merupakan data dalam bentuk skala 1-4 yang diperoleh dari penilaian panelis. Panelis diminta tanggapan pribadinya tentang kesukaan terhadap produk yogurt tempe yang dihasilkan dengan menunjukkan tingkat kesukaannya dalam bentuk angka (skala kesukaan) pada formulir yang telah disediakan. Panelis memberikan nilai berdasarkan organoleptik (inderawi) yogurt tempe (Hegel, 2012). Panelis yang digunakan sebanyak 50 panelis yang terdiri dari panelis konsumen sesuai dengan tujuan penelitian, yakni untuk mengetahui daya terima masyarakat terhadap produk tempe yang dihasilkan. Untuk mengetahui daya terima menggunakan uji kesukaan hanya dapat dilakukan oleh panelis tak terlatih (SNI, 2006). Selanjutnya data diolah menggunakan teknik analisis ragam (analysis of variance). Jika ada beda nyata, data diuji lanjut menggunakan uji BNT pada taraf signifikansi 95\% (Hanafiah, 2010).

\section{HASIL PENELITIAN DAN PEMBAHASAN}

Yogurt tempe yang dihasilkan dalam penelitian ini bertekstur lembut dan memiliki struktur yang kental. Pada dasarnya kekentalan yogurt tempe yang dihasilkan dipengaruhi oleh konsentrasi ekstrak tempe, susu skim, sukrosa dan gelatin (Amaliah, 2002). Namun dalam penelitian ini 
konsentrasi ekstrak tempe, jumlah starter, susu skim, sukrosa, dan gelatin tidak sebagai faktor yang mempengaruhi kekentalan yogurt tempe karena bahan-bahan tersebut ditambahkan ke dalam yogurt tempe dalam volume yang sama. Dengan demikian faktor yang mempengaruhi hanyalah konsentrasi ekstrak buah durian.

Keasaman yogurt tempe yang dihasilkan dalam penelitian ini berada pada kisaran $\mathrm{pH} 4$, masih berada pada skala $\mathrm{pH}$ untuk produk-produk susu fermentasi. Menurut Triwitono (2011) yogurt yang baik memiliki pH 4 - 4,5 pada akhir waktu inkubasi karena $\mathrm{pH}$ tersebut merupakan titik isoelektris protein sehingga terjadi penggumpalan, dan menurut Amaliah (2002), $\mathrm{pH}$ maksimum pada yogurt tempe yang baik adalah pada $\mathrm{pH}$ 4. Penelitian oleh Hidayat, dkk. (2013) tentang yogurt yang diperkaya dengan ekstrak buah mangga, diperoleh nilai pH yogurt yaitu kisaran 4,5-4,7.

Penerimaan umum merupakan suatu parameter yang digunakan untuk mengetahui apakah suatu produk dapat diterima oleh konsumen yang diwakili oleh sejumlah panelis (Amaliah, 2002). Hasil uji kesukaan menunjukkan bahwa yogurt tempe yang dihasilkan disukai oleh panelis. Berdasarkan hasil analisis data uji hedonik yang diperoleh dari 50 orang panelis, diketahui untuk masing-masing indikator organoleptik (warna, aroma, dan rasa) penunjukkan hasil yang berbeda nyata untuk setiap perlakuan penambahan ekstrak buah durian pada yogurt tempe (beda nyata pada taraf signifikasi 95\%). Dengan hasil yang diperoleh tersebut untuk setiap indikator organoleptik yang diuji penerimaannya, maka dapat diketahui bahwa yogurt tempe yang dapat diterima dengan baik adalah yogurt tempe dengan penambahan ekstrak buah durian $30 \%$.

Warna yogurt tempe yang dihasilkan berkisar pada warna krem cerah hingga warna krem. Gelatin dan durian menyebabkan yogurt berwarna menjadi lebih gelap. Sebaliknya skim menyebabkan warna yogurt semakin cerah. Meskipun demikian, berdasarkan Tabel 1 dan Tabel 2 panelis lebih memilih yogurt tempe yang ditambah ekstrak durian sebesar $20 \%$ dan $30 \%$. Antara kedua perlakuan tersebut tidak ada perbedaan yang nyata.

Tabel 1. Analisis sidik ragam pengaruh penambahan ekstrak buah durian terhadap penerimaan warna yogurt tempe

\begin{tabular}{llcrrr}
\hline SK & $\mathrm{db}$ & $\mathrm{JK}$ & \multicolumn{1}{c}{ KT } & F hitung & F tabel 5 \% \\
\hline Contoh (perlakuan) & 3 & 688,9 & 229,6 & 155,7 & 19,16 \\
Ulangan (Blok) & 2 & 10,2 & 3,4 & 2,31 & \\
Galat & 8 & 11,8 & 1,5 & & \\
Total & 11 & 710,9 & & & \\
\hline
\end{tabular}

Tabel 2. Pengaruh penambahan ekstrak buah durian terhadap penerimaan warna yogurt tempe

\begin{tabular}{ccc}
\hline Perlakuan & Rata-rata & Notasi \\
\hline Y0 & 131,7 & $\mathrm{a}$ \\
Y1 & 138,3 & $\mathrm{ab}$ \\
Y2 & 147,3 & $\mathrm{c}$ \\
Y3 & 151 & $\mathrm{c}$ \\
BNT 5 \% & & 7,29 \\
\hline
\end{tabular}


Ekstrak buah durian berpengaruh terhadap penerimaan konsumen dalam hal aroma dan citarasa. Ada perbedaan yang nyata antar perlakuan penambahan ekstrak buah durian (Tabel 3 dan 5). Konsumen paling menyukai yogurt tempe yang ditambah ekstrak buah durian sebesar 30\% (Tabel 4 dan 6). Menurut Amaliah (2002), aroma khas tempe dalam yogurt ditimbulkan dari aroma miselium kapang pada tempe. Selanjutnya, Najih (2012) menyatakan bahwa aroma yogurt tempe juga dipengaruhi pula oleh susu skim namun gelatin tidak mempengaruhi aroma yogurt. Akan tetapi jumlah skim yang ditambahkan sama pada semua perlakuan sehingga pengaruh skim dapat diabaikan. Hasil analisis (Tabel 4 dan 6) menunjukkan bahwa panelis paling menyukai aroma dan citarasa yogurt tempe yang ditambah sebanyak 30\% ekstrak buah durian. Dengan demikian dapat diketahui bahwa aroma durian dari ekstrak buah durian mempengaruhi aroma dan citarasa yogurt tempe.

Tabel 3. Analisis sidik ragam pengaruh penambahan ekstrak buah durian terhadap penerimaan aroma yogurt tempe

\begin{tabular}{lllrrl}
\hline SK & $\mathrm{db}$ & JK & \multicolumn{1}{c}{ KT } & F hitung & F tabel 5 \% \\
\hline Contoh (perlakuan) & 3 & 6464,9 & 2155,0 & 20,84 & 19,16 \\
Ulangan & 2 & 310,2 & 103,4 & & \\
Galat & 8 & 35,8 & 4,5 & & \\
Total & 11 & 6810,9 & & & \\
\hline
\end{tabular}

Tabel 4. Pengaruh penambahan ekstrak buah durian terhadap penerimaan aroma yogurt tempe

\begin{tabular}{ccc}
\hline Perlakuan & Rata-rata & Notasi \\
\hline Y0 & 71,3 & $\mathrm{a}$ \\
Y1 & 79,7 & $\mathrm{~b}$ \\
Y2 & 107,3 & $\mathrm{c}$ \\
Y3 & 130 & $\mathrm{~d}$ \\
BNT 5\% & & 3,99 \\
\hline
\end{tabular}

Selama penyimpanan, warna dan aroma yogurt tempe relatif stabil, namun rasa yogurt tempe menjadi semakin asam. Hal ini mungkin karena aktivitas metabolisme bakteri yang masih berlangsung meskipun lambat pada yogurt tempe selama penyimpanan. Pada penyimpanan hingga hari ke empat, $\mathrm{pH}$ yogurt tempe pada $\mathrm{pH} 4$, masih kental, dan tidak berbau sehingga yogurt tersebut masih tetap aman untuk dikonsumsi (tidak rusak). Yogurt dikatakan rusak jika terjadi perubahan konsistensi (kekentalan), penyimpangan $\mathrm{pH}$, timbul bau busuk dan terbentuk gas (Sugiarto, 2007).

Tabel 5. Analisis sidik ragam pengaruh penambahan ekstrak buah durian terhadap

\begin{tabular}{lrrrrr}
\multicolumn{2}{c}{ penerimaan rasa yogurt tempe } & & & \\
\hline SK & db & JK & KT & F hitung & $\begin{array}{l}\text { F tabel 5 } \\
\%\end{array}$ \\
\hline Contoh (perlakuan) & 3 & 6464,9 & 2155,0 & 20,84 & 19,16 \\
Ulangan & 2 & 310,2 & 103,4 & & \\
Galat & 8 & 35,8 & 4,5 & & \\
Total & 11 & 6810,9 & & & \\
\hline
\end{tabular}


Tabel 6. Pengaruh penambahan ekstrak buah durian terhadap penerimaan rasa yogurt tempe

\begin{tabular}{ccc}
\hline Perlakuan & Rata-rata & Notasi \\
\hline Y0 & 72 & $\mathrm{a}$ \\
Y1 & 82,3 & $\mathrm{~b}$ \\
Y2 & 116 & $\mathrm{c}$ \\
Y3 & 144,3 & $\mathrm{~d}$ \\
BNT 5\% & & 2,05 \\
\hline
\end{tabular}

Kandungan gizi yang terdapat pada yogurt sesuai dengan bahan yang digunakan dalam pembuatan yogurt (Syamsir, 2009). Kandungan utama pada yogurt tempe dalam penelitian ini terdiri dari protein dan lemak.
Protein terutama berasal dari ektrak tempe dan buah durian, sedangkan lemak terutama berasal ekstrak buah durian. Analisis kandungan gizi dari yogurt tempe dalam penelitian ini dapat dilihat pada Tabel 7.

Tabel 7. Kandungan gizi yogurt tempe

\begin{tabular}{llll}
\hline No. & Zat gizi & \multicolumn{2}{c}{$\begin{array}{c}\text { Persentase penambahan ekstrak buah durian } \\
\mathbf{0 \%}\end{array}$} \\
\hline 1. & Protein & $3,74 \%$ & $3,14 \%$ \\
2. & Lemak & $1,19 \%$ & $1,47 \%$ \\
3. & Vitamin $\mathrm{O}$ & $25,25 \mathrm{mg}$ & $35,20 \mathrm{mg}$ \\
4. & $\mathrm{Ca}$ & $0,024 \%$ & $0,147 \%$ \\
5. & $\mathrm{~K}$ & $0,042 \%$ & $0,258 \%$ \\
\hline
\end{tabular}

Tabel 8. Syarat mutu yogurt

\begin{tabular}{|c|c|c|c|c|c|c|c|c|}
\hline & Kriteria Uji & Satuan & \multicolumn{3}{|c|}{$\begin{array}{l}\text { Yogurt tanpa perlakuan } \\
\text { panas setelah fermentasi }\end{array}$} & \multicolumn{3}{|c|}{$\begin{array}{l}\text { Yogurt dengan perlakuan } \\
\text { panas setelah fermentasi }\end{array}$} \\
\hline No. & Kriteria Uji & Satuan & Yogurt & $\begin{array}{c}\text { Yogurt } \\
\text { rendah } \\
\text { lemak }\end{array}$ & $\begin{array}{c}\text { Yogurt } \\
\text { tanpa } \\
\text { lemak }\end{array}$ & Yogurt & $\begin{array}{c}\text { Yogurt } \\
\text { rendah } \\
\text { lemak }\end{array}$ & $\begin{array}{c}\text { Yogurt } \\
\text { tanpa } \\
\text { lemak }\end{array}$ \\
\hline 1 & Keadaan & & & & & & & \\
\hline 1.1 & Penampakan & - & \multicolumn{3}{|c|}{ cairan kental - padat } & \multicolumn{3}{|c|}{ cairan kental - padat } \\
\hline 1.2 & $\mathrm{Bau}$ & - & \multicolumn{3}{|c|}{ normal/khas } & \multicolumn{3}{|c|}{ normal/khas } \\
\hline 1.3 & Rasa & - & \multicolumn{3}{|c|}{ asam/khas } & \multicolumn{3}{|c|}{ asam/khas } \\
\hline 1.4 & Konsistensi & - & \multicolumn{3}{|c|}{ homogen } & \multicolumn{3}{|c|}{ homogen } \\
\hline 2 & $\begin{array}{l}\text { Kadar lemak } \\
\text { (b/b) }\end{array}$ & $\%$ & $\min .3,0$ & $0,6-2,9$ & $\begin{array}{c}\text { maks. } \\
0,5\end{array}$ & $\begin{array}{c}\min . \\
3,0\end{array}$ & $0,6-2,9$ & $\begin{array}{c}\text { maks. } \\
0,5\end{array}$ \\
\hline 3 & $\begin{array}{l}\text { Total padatan } \\
\text { susu bukan } \\
\text { lemak }(\mathrm{b} / \mathrm{b})\end{array}$ & $\%$ & \multicolumn{3}{|c|}{$\min .8,2$} & \multicolumn{3}{|c|}{$\min .8,2$} \\
\hline 4 & $\begin{array}{l}\text { Protein }(\mathrm{Nx} 6,38) \\
(\mathrm{b} / \mathrm{b})\end{array}$ & $\%$ & \multicolumn{3}{|c|}{$\min .2,7$} & \multicolumn{3}{|c|}{$\min .2,7$} \\
\hline
\end{tabular}

\section{SNI 2981:2009}

Kandungan protein dan lemak yoghurt tempe dalam penelitian ini masih sesuai dengan SNI tahun 2009 untuk standar yogurt (Tabel 8). Kandungan protein yogurt tempe dalam penelitian ini lebih rendah jika 
dibandingkan dengan kadar protein pada hasil penelitian sejenis yang dilakukan oleh Amaliah (2002) yakni 3,94 \%, dengan menggunakan perbandingan tempe dan air yang sama yakni $1 \mathrm{~kg}$ tempe dalam 6 liter air. Hal ini dapat disebabkan karena dalam penelitian Amaliah tersebut susu tempe tidak disaring. Penyaringan bertujuan untuk menghindari terbentuknya endapan dari ampas tempe sehingga dapat dihasillkan tekstur yang kompak (homogen). Pada dasarnya yogurt yang baik dihasilkan dari susu yang homogen (Sugiarto, 2007). Penelitian sejenis lainnya (Kusumaningrum, 2004), dihasilkan yogurt dengan kadar protein sebesar $3,81 \%$ dengan konsentrasi tempe yang lebih tinggi yaitu 100 gram tempe dalam $200 \mathrm{~mL}$ air. Kadar protein yogurt tempe tanpa penambahan ekstrak buah durian lebih tinggi dibanding yogurt yang ditambah ekstrak buah durian. Hal dapat dipahami bahwa semakin tinggi kadar tempe maka kandungan proteinnya juga semakin tinggi. Sebaliknya kadar gizi lainnya seperti lemak, vitamin, $\mathrm{C}, \mathrm{Ca}$, dan $\mathrm{K}$ cenderung lebih rendah pada yogurt tanpa penambahan ekstrak buah durian. Hal tersebut ada kemungkinan disebabkan karena kandungan kadar gizi tersebut pada pergram buah durian lebih tinggi dibanding pada tempe. Sehingga yogurt yang ditambah ekstrak buah durian memiliki kandungan lemak, vitamin $\mathrm{C}, \mathrm{Ca}$, dan $\mathrm{K}$ lebih tinggi dibanding murni yogurt tempe. Lemak sangat mempengaruhi cita rasa yoghurt, terbukti dalam penelitian ini yogurt yang ditambah $30 \%$ ekstrak buah durian paling disukai. Dalam penelitian oleh Askar dan Sugiarto (2005), ternyata dari hasil uji organoleptik pada yogurt menunjukkan bahwa yogurt yang berbahan dasar susu murni lebih disukai dibanding susu skim (susu murni mengandung kadar lemak labih tinggi dibanding susu skim).

\section{KESIMPULAN}

Penambahan ekstrak buah durian berpengaruh terhadap penerimaan warna, aroma dan rasa yogurt tempe. Yogurt tempe yang paling diterima (disukai) adalah yogurt tempe dengan penambahan ekstrak buah durian $30 \%$.

\section{DAFTAR PUSTAKA}

Amaliah, A. 2002. Pembuatan Soygurt Dengan Media Ekstrak Tempe. Skripsi S1 Institut Pertanian Bogor.

Arbi, A.S. 2012. Analisis Karakteristik Mutu Pangan dan Keterterimaan Produk. Modul Kuliah Pengendalian Mutu Pada Industri (online):http://www.scribd.com Diakses tanggal 22 Mei 2012.

Askar, S dan Sugianto. 2005. Uji Kimiawi dan Organoleptik Sebagai Uji Mutu Yoghurt. Prosiding Temu Teknis tenaga Fungsional Pertanian 2005.

Fuzhu, F. 2010. Yogurt Tempe Матри Perbaiki Kerusakan Hati. (online): http://fuzudhoz.blogspot.com. Diakses tanggal 22 Mei 2012.

Hanafiah, K.A. 2010. Rancangan Percobaan. Jakarta: Rajawali Press.

Hegel. 2012. Uji Hedonik. (online) : http://www.scribd.com. Diakses tanggal 22 Mei 2012

Hidayat, I. R., Kusrahayu dan S. Mulyani. (2013). Total Bakteri Asam Laktat, Nilai pH Dan Sifat Organoleptik Drink Yoghurt Dari Susu Sapi Yang Diperkaya Dengan Ekstrak Buah Mangga. Animal Agriculture Journal, Vol. 2. No. 1, 2013, p 160 167. Online at : http://ejournals1.undip.ac.id/index.php/aaj 
Kusumaningrum, E.N. 2004. Pembuatan Minuman Soygurt Dari Sari Tempe Dengan Menggunakan Bakteri Lactobacillus plantarum. Jurnal Matematika, Sains dan Teknologi, Vol.5 No. 1, Maret 2004.

Machin, A. 2012. Potensi Hidrolisat Tempe Sebagai Penyedap Rasa Melalui Pemanfaatan Ekstrak Buah Nanas. Biosantifika 4 (2) (2012). Berkala Ilmiah Biologi. http://journal.unnes.ac.id/nju/index.php/ biosaintifika

Najih, L. 2012. Mutu Gizi Susu Tempe Fermentasi DenganPenambahan Jenis Bahan Pengental. Skripsi S1 Teknologi Pangan Universitas Muhammadiyah Semarang.

Standar Nasional Indonesia.. 01. 2346.2006. Petunjuk Pengujian Organoleptik dan atau Sensori. Jakarta: Badan Standarisasi Nasional. (online) : http://www.bsn.go.id. Diakses tanggal 22 Mei 2012.

SNI 2981:2009. Standar Nasional Indonesia (SNI) Yogurt.

Sugiarto. 2007. Proses Pembuatan dan Penyimpanan Yogurt Yang Baik. Lokakarya Fungsional Non Peneliti, Balai Penelitian Ternak Ternak. Ciawi Bogor.

Syamsir, E. 2009. Peluang Usaha Yogurt. http://ilmupangan.blogspot.com, Diakses tanggal 22 Juli 2012.

Tridiyani, A. 2011. Panelis Dalam Pengujian Sensori. (online): http://3diyanisa3.blogspot.co. Diakses tanggal 22 Juli 2012

Widodo, W. 2002. Bioteknologi Fermentasi Susu. Malang: Pusat Pengembangan
Bioteknologi Universitas

Muhamadiyah Malang. 